\title{
Optimized Frequency Measures for Monitoring Trends in Tallgrass Prairie
}

\author{
Michael D. DeBacker, ${ }^{1}$ John S. Heywood, ${ }^{2}$ and Lloyd W. Morrison ${ }^{3}$ \\ Authors are ${ }^{1}$ Ecologist-Program Coordinator and ${ }^{3}$ Quantitative Ecologist, National Park Service, Heartland Inventory and Monitoring Network, 6424 \\ West Farm Road 182, Republic, MO 65738, USA; and ${ }^{2}$ Professor, Department of Biology, Missouri State University, 901 South National Avenue, \\ Springfield, MO 65897, USA.
}

\begin{abstract}
Prairies exhibit a bimodal frequency distribution of patch occupancy with a few dominant species accounting for most of the primary production and plant biomass and numerous other species occurring infrequently over time and space. Consequently, management interest is often focused on the abundance of common species, and on the persistence of less common species. We used spatially nested arrays of various sized plots to simultaneously measure species' persistence and abundance at Tallgrass Prairie National Preserve, Kansas. Larger plots captured more species, with 127 species identified at the 10-m scale. Smaller plots, however, provided useful frequency data for measuring the abundance of common species. We defined a plot frame size that delivers a frequency in a $20-50 \%$ target range as the optimal plot size, and the frequency of a species sampled at its optimal plot size is termed the optimized frequency. Optimized frequency was estimated for 27 common species for the years $2002-$ 2006. Of the nine perennial grasses in this group, five exhibited significant interannual variation within the 5-yr period. Bouteloua curtipendula exhibited a significant linear change over the 5-yr period, decreasing in frequency over time. From year to year, changes in optimized frequency among the 27 common species varied in both their trajectory (i.e., the average change), and amplitude (i.e., the average magnitude of change). Between 2005 and 2006, the average change in optimized frequency was $-9.1 \%$, the only year with an overall declining trajectory. The declining trajectory between 2005 and 2006 was significantly different from the increasing trajectories observed between 2002 and 2003 and between 2004 and 2005. No significant differences were observed in amplitude. We offer these techniques for aggregating information from multiple spatial scales to characterize the amplitude and trajectory of community-wide changes as tools to help scientists convey the results of multiscale research projects to land managers.
\end{abstract}

\section{Resumen}

Las praderas exhiben una distribución bimodal de frecuencia de ocupación de parches con pocas especies dominantes que reúnen la mayor parte de la producción primaria y fitomasa, y una gran cantidad de otras especies ocurren de modo infrecuente a través del tiempo y el espacio. Por lo tanto, el manejo frecuentemente se enfoca en la abundancia de las especies comunes y la persistencia de las especies menos comunes. Se utilizaron matrices espaciales anidadas de parcelas de varios tamaños para medir la persistencia y abundancia de especies de modo simultáneo en la Reserva Nacional del Tallgrass Prairie en Kansas. Las parcelas más grandes capturaron más especies, con 127 especies identificadas a la escala de diez metros. Las parcelas más pequeñas, sin embargo, proveyeron datos de frecuencia útiles para medir la abundancia de especies comunes. Se definió como tamaño óptimo a una parcela que provee una frecuencia dentro del 20-50\% del rango deseado, y la frecuencia de una especie muestreada con su tamaño óptimo de parcela se denominó frecuencia optimizada. Se estimó la frecuencia optimizada para 27 especies comunes para el período 2002-2006. De los nueve pastos perennes en este grupo, cinco exhibieron una variación interanual significativa dentro del período de cinco años considerado. De año a año, los cambios en la frecuencia optimizada entre las 27 especies comunes variaron tanto en su trayectoria (es decir, el cambio promedio) como en su amplitud (es decir, la magnitud promedio del cambio). Entre 2005 y 2006, el cambio promedio en frecuencia optimizada fue $-9.1 \%$, el único año con una trayectoria general decreciente. La trayectoria decreciente entre 2005 y 2006 difirió significativamente de las trayectorias crecientes observadas entre 2002-2003 y 2004-2005. No se observaron diferencias significativas en amplitud. Se ofrece una descripción de técnicas para integrar información de múltiples escalas espaciales para caracterizar la amplitud y trayectoria de cambios a escala de comunidades. Dichas técnicas pueden ser usadas como herramientas para ayudar a los investigadores a transmitir a los profesionales encargados del manejo de las tierras resultados de investigación realizada a múltiples escalas.

Key Words: grassland sampling, multiscale sampling, plant frequency, species abundance, species persistence

$\overline{\text { Views, statements, findings, conclusions, recommendations, and data in this report are those of }}$ the author(s) and do not necessarily reflect views and policies of the National Park Service, U.S. Department of the Interior. Mention of trade names or commercial products does not constitute endorsement or recommendation for use by the National Park Service.

Correspondence: Michael D. DeBacker, National Park Service, Heartland Network, 6424 West Farm Road 182, Republic, MO 65738, USA. Email: mike_debacker@nps.gov

Manuscript received 1 December 2009; manuscript accepted 9 January 2011.

\section{INTRODUCTION}

The tallgrass prairie ecosystem once spread across more than 60 million ha from southern Texas to southern Manitoba. It is now estimated that as little as 1-4\% (0.6-2.4 million ha) of the original tallgrass prairie remains (Samson and Knopf 1994). Such grassland ecosystems are maintained by a complex 
disturbance regime including frequent large- and small-scale disturbances. The direct and interactive effects of periodic fire and ungulate grazing are widely recognized as critical components of the natural disturbance regime in tallgrass prairie ecosystems (Collins 1987; Anderson 1990; Knapp et al. 1999; Fuhlendorf and Engel 2004; Fuhlendorf et al. 2008). Fire and grazing affect belowground productivity (Rice et al. 1998), aboveground standing crop and litter cover, vegetation structure (Collins and Gibson 1990), nitrogen mineralization rates (Anderson et al. 2006), productivity, microsite characteristics (e.g., soil moisture, light), species diversity (Collins and Steinauer 1998), and naturalized plant species richness (Smith and Knapp 1999).

Periodic drought, extreme heat and cold, and variable weather from year to year also affect the spatial and temporal dynamics in tallgrass prairie (Bragg 1995; Knapp and Seastedt 1998). As a result of multiple interacting disturbances and variable climatic extremes, grassland systems consist of dynamic mosaics of vegetation patches scattered across the landscape that are highly variable in both space and time (Collins and Glenn 1988, 1991; Collins 1992; Vinton et al. 1993; Fuhlendorf and Engle 2001, 2004).

Prairies exhibit a bimodal frequency distribution of patch occupancy. A few dominant species account for most of the primary production and plant biomass, and effectively control community structure. Many other species occur infrequently over time and space (Collins and Glenn 1990; Bartha et al. 1995; Freeman 1998). Hanski's (1982) core-satellite species metapopulation model predicts a bimodal distribution of species abundances. Grime, in his 1998 study of the relationship between species diversity and ecosystem function, similarly classified species as dominant, subordinate, or transient. Gibson et al. (1999) describe Hanski's model as the theoretical basis for Grime's classification.

The juxtaposition of many uncommon species throughout a matrix of dominant grasses in tallgrass prairie creates challenges for land managers charged with monitoring and maintaining healthy grasslands. Estimates of population abundance for most tallgrass prairie species are not informative given their scarcity across space and time. For managers of protected lands, the relevant information is whether these species persist in the community over time. For the most common species, on the other hand, managers are interested in their abundance. Multiscale sample designs are effective for monitoring species persistence by capturing uncommon species in large plots. At the same time, multiscale designs provide useful data for monitoring the abundance of common species through their frequency of occurrence in smaller plots (Peet et al. 1998; Stohlgren et al. 1998; James et al. 2009). Although the literature contains a variety of suggestions for selecting plot sizes for the acquisition of frequency data (reviewed by Heywood and DeBacker 2007), we have shown that frequency data are most sensitive to changes in underlying plant density when they are acquired using a plot size that yields an average frequency between 20\% and 50\% (Heywood and DeBacker 2007). In the present study we introduce the term optimized frequency for observed frequencies falling within this range. Because different species will be present at very different densities, a range of plot sizes will be required to capture optimized frequency data.
The Heartland Inventory and Monitoring Network of the National Park Service develops and implements protocols for monitoring prairie fauna, flora, and ecosystems. Monitoring objectives for prairie plant communities are to describe the species composition, structure, and diversity of the community; to monitor those elements for change; and to determine if changes are correlated with management actions. Here we demonstrate the utility of our multiscale, frequency-based method for monitoring changes in core and satellite species by presenting data collected over a 5 -yr period from Tallgrass Prairie National Preserve located in the Flint Hills of Kansas. We offer a novel approach to characterize the amplitude and trajectory of change in the community through examining changes in optimized frequency for multiple species simultaneously. We contend these methods are more effective for providing useful information to land managers than typical species-centric approaches. Specifically, we investigate 1) decision rules for assigning a plot frame size that yields an optimized frequency measure for abundant species, 2) the reliability of an assigned frame size to deliver species frequency measures within an acceptable range over time, and 3) the aggregation of results from multiple spatial scales and species into useful information products for land managers.

\section{METHODS}

\section{Study Area}

In the Flint Hills of Kansas, rangeland overlaps with the largest contiguous untilled tallgrass prairie tracts in the United States (Knapp and Seastedt 1998). Land management in the Flint Hills often consists of annual spring burning of bluestem prairie to support grazing of feeder cattle. In $2007,50 \%$ and $25 \%$ of Flint Hills rangeland was leased for season-long and partialseason grazing, respectively (Kansas Department of Agriculture 2007). Annual spring burning controls woody plants (Bragg and Hurlbert 1976) and potentially increases forage palatability and cattle weight gain (Anderson et al. 1970; Allen et al. 1976). Partial-season grazing includes intensive early stocking, which matches double stocking rates with the period of highest grass productivity during May through mid-July (Smith and Owensby 1978).

This study was conducted at Tallgrass Prairie National Preserve (TAPR), the first National Park Service area established specifically for the preservation, protection, and interpretation of the tallgrass prairie ecosystem (Hiebert 1998). Initially known as the Spring Hill Ranch area and continuously grazed for cattle production for over $120 \mathrm{yr}$, TAPR contains over 3700 hectares of unplowed tallgrass prairie in the Flint Hills physiognomic province of Kansas. Grazing practices have changed over time, although have generally consisted of stocking with cattle and spring burning. This management does not fully simulate the temporal or spatial variability of a native tallgrass ecosystem (Robbins and Ortega-Huerta 2002), particularly the seasonality and behavior of fire.

\section{Study Design}

Our monitoring method was adapted from the Konza Prairie Biological Research site in Manhattan, Kansas (Knapp et al. 1998), and included recording frequency in large, $10-\mathrm{m}^{2}$ 
sample frames (with the addition of spatially nested subplots to the design). Permanent sample sites were randomly located and data from sites were pooled for preserve-wide results. At each site, two parallel $50-\mathrm{m}$ transects were located $20 \mathrm{~m}$ apart, with five $10-\mathrm{m}^{2}$ circular plots located along each transect. Subplots of $0.01 \mathrm{~m}^{2}, 0.1 \mathrm{~m}^{2}$, and $1 \mathrm{~m}^{2}$ were nested within each of the 10 $\mathrm{m}^{2}$ plots (Fig. 1). The transect pair represents the primary sample unit, and is referred to as the sample site. The plot is the secondary sample unit and was used to collect ground flora data. Species' frequency refers to the percentage of plots occupied per sample site. All species rooted inside the plot were identified beginning with the $0.01-\mathrm{m}^{2}$ plot. The $0.1-\mathrm{m}^{2}$ plot was then searched for additional species and so forth, working up to the largest plot (James et al. 2009). Data were collected annually between 30 September and 13 October from 18 sample sites from 2002 through 2006. Species richness was tallied across all sites $(n=18)$ and years $(n=5)$ and then averaged at each spatial scale.

\section{Data Analysis}

The frequency (percentage of plots occupied per sample site) of a particular species depends on the spatial scale over which it is sampled (i.e., plot size), and is sensitive to changes in underlying density. The optimal frequency, defined as the frequency returned by the plot size that is most sensitive to changes in underlying density, varies between $20 \%$ and $50 \%$ depending on the degree to which local density is structured in space (Heywood and DeBacker 2007). Of the four plot sizes used in this study, we refer to the plot size that delivers a frequency in this $20-50 \%$ target range as the optimal plot size, and the frequency of a species sampled using its optimal plot size is termed the optimized frequency.

The optimal plot size was determined for each of 27 abundant species (i.e., all species occurring at $>15 \%$ frequency at the 10 $\mathrm{m}^{2}$ scale) by assigning species to a plot frame size that yielded, on average over the 5 -yr study, a frequency nearest $35 \%$ (i.e., the midpoint of the $20-50 \%$ target range). Once a plot frame size was assigned, frequency was calculated from the same plot frame size each year of the study. The percentage of plots in which a species occurred at this spatial scale was defined as the species' optimized frequency for that year. We determined the percentage of each species' annual optimized frequency measures falling within $\pm 20 \%$ of the $35 \%$ target (i.e., $15-55 \%$ ), which was defined as an acceptable range of frequencies.

To evaluate changes over time, we plotted individual species' optimized frequencies for each year (in the interest of space, here we focus only on nine warm-season grass species to illustrate the method). Repeated measures analyses of variance (ANOVAs) were applied to each species separately to test for any differences among years. Sampling sites were the subjects and time (year) was the within-subject factor. An arc-sine square-root transformation was applied to normalize the proportional data (Kutner et al. 2005). Both multivariate and univariate approaches to analyzing the repeated-measures design were used and yielded similar results in terms of statistical significance of the within-subjects effect (time); multivariate results are presented here (using the Wilks lambda statistic) because they are based on less restrictive assumptions (Norusis 2008). Simple linear regressions of annual mean

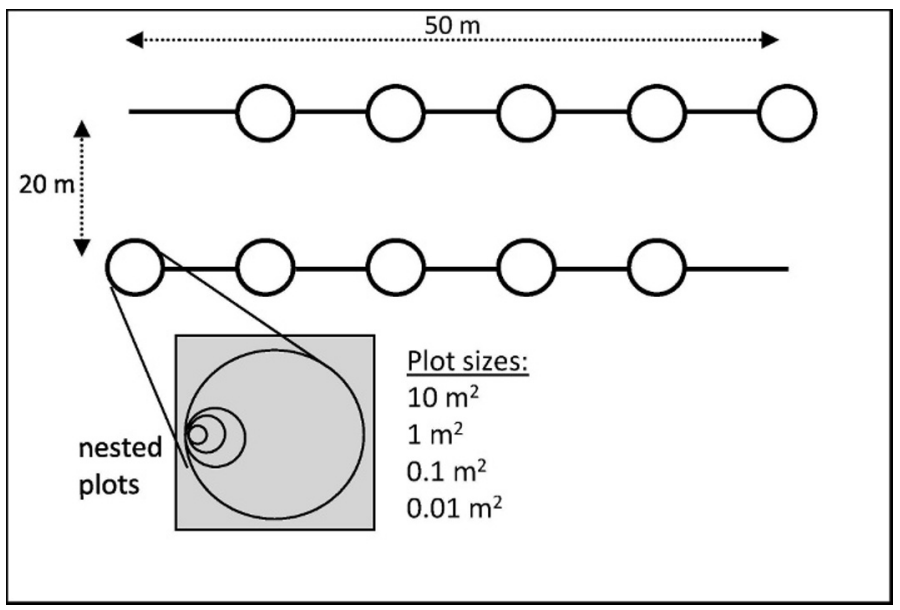

Figure 1. Placement of transects and plots at a sample site. Design includes large $10-\mathrm{m}^{2}$ plot frames with nested $1-\mathrm{m}^{2}, 0.1-\mathrm{m}^{2}$, and $0.01-\mathrm{m}^{2}$ plot frames.

frequency on year were also applied to each species separately to test for linear trends over time.

The distribution of change in optimized frequency across the 27 most abundant species was plotted for each 1-yr interval. Distributions were ordered by the magnitude of change, independent of species identities. From these data, we calculated the trajectory of yearly change, defined as the average across species of the change in optimized frequency between pairs of consecutive years; and the amplitude of yearly change, defined as the average across species of the absolute value of the change in optimized frequency between consecutive pairs of years. Differences between pairs of years for actual and absolute values were evaluated with ANOVA.

\section{RESULTS}

As predicted, the estimated frequency distribution of patch occupancy was bimodal (Fig. 2). Twenty species (16\% of all species observed) occurred in $90 \%$ or more of the unique site by year combinations $(n=90)$, whereas 77 species occurred in fewer than $10 \%$ of the sites. As plot frame size increased, not surprisingly, so did the total number of species captured. The $0.01 \mathrm{~m}^{2}, 0.1 \mathrm{~m}^{2}, 1 \mathrm{~m}^{2}$, and $10-\mathrm{m}^{2}$ plots captured $43,69,104$, and 127 species, respectively.

Three annual species, four short-lived forbs, seven long-lived forbs, four perennial grasses and sedges, and nine warm-season grasses comprise the 27 most abundant species based on their 5 -yr average frequency. Each of these species was assigned an optimal plot size (Tables 1 and 2). Over the 5 -yr period, $89 \%$ of all frequency estimates fell within the $15-55 \%$ acceptable range (Tables 2 and 3). About half of the frequency estimates outside of the acceptable range resulted from species assigned to the $10-\mathrm{m}^{2}$ frame (which included $56 \%$ of the species). Of those "misses," all fell below the lower threshold of $15 \%$, although most of these low frequencies occurred in a single year, 2002 (Table 3). Annual and short-lived forbs (which represented only $26 \%$ of the abundant species), accounted for 5 of the 10 largest changes in optimized frequency from year to year. In contrast, perennial, warm-season grasses accounted for 


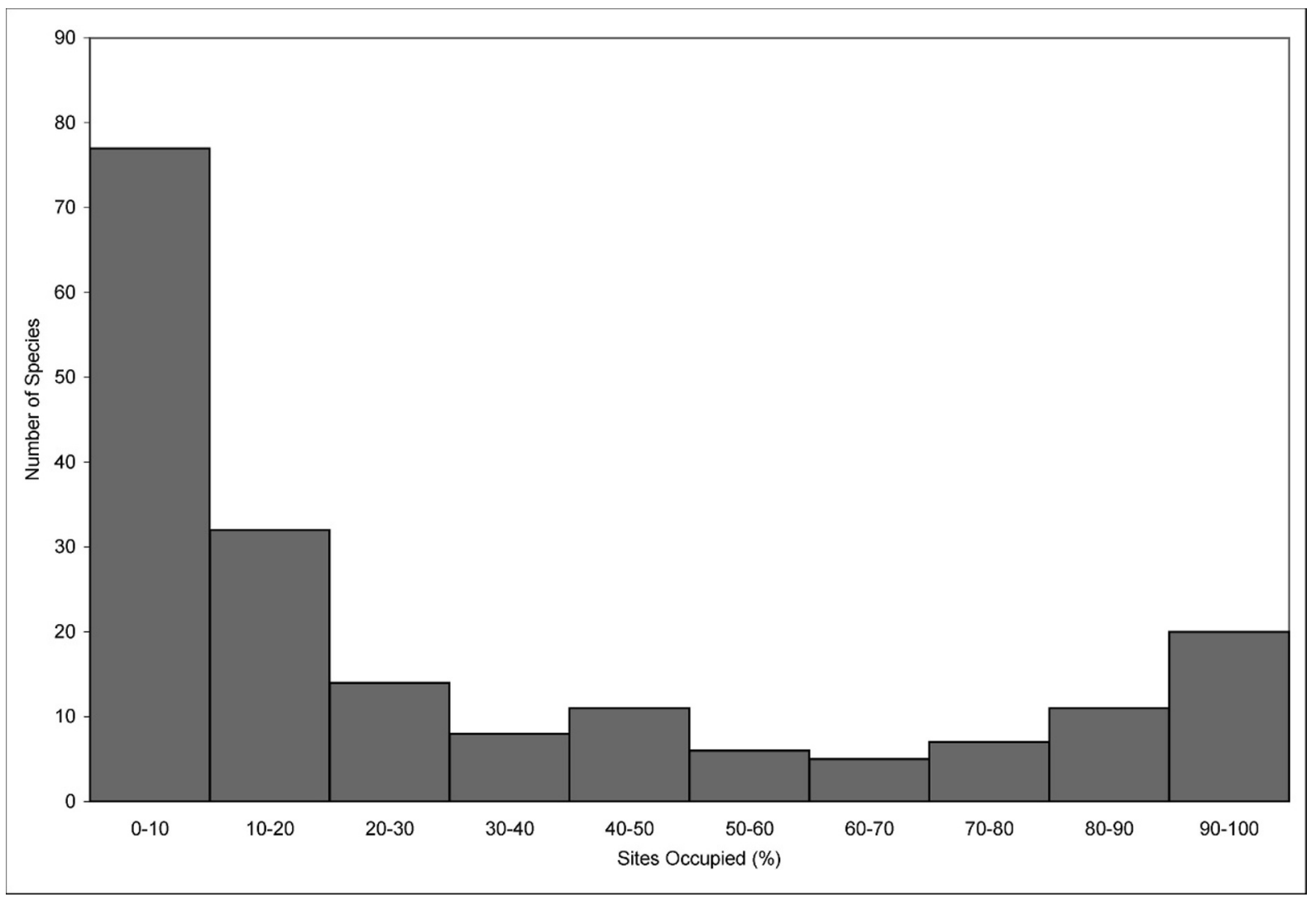

Figure 2. Frequency distribution of site occupancy at Tallgrass Prairie National Preserve for the period 2002-2006, based on 18 sampling sites.

$33 \%$ of the abundant species, but only one of the largest yearto-year changes (Table 2).

The nine warm-season grass species exhibited different patterns of abundance over time (Fig. 3). Five species exhibited significant interannual variation in mean frequency within the 5 -yr period (Andropogon gerardii, $F=5.91, P=0.005$; Bouteloua curtipendula, $F=3.49, P=0.036$; Schizachyrium scoparium, $F=5.82, P=0.006 ;$ Panicum virgatum, $F=7.86$, $P=0.002$; Sorghastrum nutans, $F=6.06, P=0.005$; repeated measures ANOVAs with $\mathrm{df}=4,14$ for all species). Marginally significant changes were found for one species (Buchloe dactyloides, $F=2.45, P=0.095)$, and no significant changes were observed for three species (Sporobolus asper, $F=2.06$, $P=0.14 ;$ Boutelona gracilis, $F=0.99, P=0.45 ;$ Boutelona birsuta, $F=1.30, P=0.32$ ). Only one species, $B$. curtipendula, exhibited a significant linear change over the 5 -yr period,

Table 1. Number of species assigned to four frame sizes for yielding optimized frequency measures. A total of 100 species occurred too infrequently to obtain optimized frequency information.

\begin{tabular}{lc}
\hline Plot frame size & No. of species \\
\hline$<0.01 \mathrm{~m}^{2}$ & 1 \\
$0.01 \mathrm{~m}^{2}$ & 2 \\
$0.1 \mathrm{~m}^{2}$ & 4 \\
$1 \mathrm{~m}^{2}$ & 4 \\
$10 \mathrm{~m}^{2}$ & 16 \\
$>10 \mathrm{~m}^{2}$ & $100^{1}$ \\
\hline
\end{tabular}

${ }^{1}$ Species with less than $15 \%$ average frequency at the $10-\mathrm{m}^{2}$ scale. decreasing in optimized frequency over time $(F=66.58$, $\mathrm{df}=1,3, P=0.004, R^{2}=0.96$; simple linear regression).

From year to year, there was considerable variation in both the proportion of species showing increases and decreases in frequency and the range of interannual change (Fig. 4). In $2005,63 \%$ of species increased or remained the same in estimated frequency from the previous year, while only $37 \%$ declined (Fig. 4A). In 2006, 67\% of species declined in estimated frequency from the previous year, while only $33 \%$ increased or remained equal (Fig. 4B). In 2003, the range of changes in species' estimated frequency from the previous year was $-20 \%$ to $56 \%$ (data not shown). In 2005 , the range was nearly half that, from $-22 \%$ to $25 \%$.

ANOVA revealed significant differences in the trajectory (mean actual value) of yearly change in species' optimized frequency $(F=4.57$; $\mathrm{df}=3,104 ; P=0.005)$. Pairwise comparisons based on Tukey's test indicated significant differences between 2002-2003 and 2005-2006 ( $q=3.365, P=0.0058)$, and between 2004-2005 and 2005-2006 $(q=2.916$, $P=0.0222$; Fig. 5). No significant differences in the amplitude (mean absolute value) of yearly change in species' optimized frequency were observed $(F=1.29 ; \mathrm{df}=3,104 ; P=0.282$; Fig. 5).

\section{DISCUSSION}

The observed bimodal frequency distribution of species occupancy is consistent with other studies in tallgrass prairie. Gotelli and Simberloff (1987) found a similar core-satellite 
Table 2. Life form, optimal plot size, optimized frequency and change from the previous year for 27 species. Species are ranked from most to least abundant based on their 5-yr average optimized frequency in the order of increasing optimal plot size.

\begin{tabular}{|c|c|c|c|c|c|c|c|c|c|c|c|c|}
\hline & \multirow[b]{2}{*}{ Life form ${ }^{1}$} & \multirow{2}{*}{$\begin{array}{l}\text { Optimal } \\
\text { plot size }\end{array}$} & \multirow{2}{*}{$\begin{array}{c}2002 \\
\text { Frequency }\end{array}$} & \multicolumn{2}{|c|}{2003} & \multicolumn{2}{|c|}{2004} & \multicolumn{2}{|c|}{2005} & \multicolumn{2}{|c|}{2006} & \multirow{2}{*}{$\begin{array}{l}\text { 5-yr average } \\
\text { frequency }\end{array}$} \\
\hline & & & & Frequency & Change & Frequency & Change & Frequency & Change & Frequency & Change & \\
\hline Andropogon gerardii & WSG & $0.01 \mathrm{~m}^{2}$ & 56.7 & 63.9 & 7.2 & 70.6 & 6.7 & 73.9 & 3.3 & 46.1 & -27.8 & 51.9 \\
\hline Schizachyrium scoparium & WSG & $0.01 \mathrm{~m}^{2}$ & 49.4 & 39.4 & -10.0 & 50.0 & 10.6 & 48.9 & -1.1 & 61.7 & 12.8 & 41.6 \\
\hline Bouteloua curtipendula & WSG & $0.01 \mathrm{~m}^{2}$ & 52.8 & 47.8 & -5.0 & 42.2 & -5.6 & 36.7 & -5.6 & 36.1 & -0.6 & 35.9 \\
\hline Panicum virgatum & WSG & $0.1 \mathrm{~m}^{2}$ & 21.7 & 41.7 & 20.0 & 43.9 & 2.2 & 32.8 & -11.1 & 33.9 & 1.1 & 29.0 \\
\hline Aster ericoides & LF & $0.1 \mathrm{~m}^{2}$ & 27.8 & 33.9 & 6.1 & 37.2 & 3.3 & 27.8 & -9.4 & 38.9 & 11.1 & 27.6 \\
\hline Sorghastrum nutans & WSG & $0.1 \mathrm{~m}^{2}$ & 39.4 & 19.4 & -20.0 & 31.1 & 11.7 & 36.7 & 5.6 & 14.4 & -22.2 & 23.5 \\
\hline Sporobolus asper & WSG & $0.1 \mathrm{~m}^{2}$ & 25.0 & 28.3 & 3.3 & 32.8 & 4.4 & 20.0 & -12.8 & 20.0 & 0.0 & 21.0 \\
\hline Ambrosia psilostachya & SF & $1 \mathrm{~m}^{2}$ & 19.4 & 36.7 & 17.2 & 52.2 & 15.6 & 75.0 & 22.8 & 33.9 & -41.1 & 36.2 \\
\hline Dichanthelium spp. & GGL & $1 \mathrm{~m}^{2}$ & 41.1 & 48.3 & 7.2 & 40.5 & -7.8 & 37.2 & -3.3 & 43.3 & 6.1 & 35.1 \\
\hline Amorpha canescens & LF & $1 \mathrm{~m}^{2}$ & 33.9 & 33.3 & -0.6 & 43.9 & 10.6 & 48.3 & 4.4 & 13.9 & -34.4 & 28.9 \\
\hline Amphiachyris dracunculoides & $A$ & $1 \mathrm{~m}^{2}$ & 0.0 & 56.1 & 56.1 & 45.0 & -11.1 & 22.8 & -22.2 & 29.4 & 6.7 & 25.6 \\
\hline Solidago missouriensis & SF & $1 \mathrm{~m}^{2}$ & 5.0 & 43.9 & 38.9 & 15.6 & -28.3 & 16.1 & 0.6 & 17.2 & 1.1 & 16.3 \\
\hline Eragrostis spectabilis & GGL & $10 \mathrm{~m}^{2}$ & 48.3 & 40.0 & -8.3 & 52.8 & 12.8 & 52.2 & -0.6 & 18.9 & -33.3 & 35.4 \\
\hline Bouteloua hirsuta & WSG & $10 \mathrm{~m}^{2}$ & 45.6 & 27.2 & -18.3 & 40.0 & 12.8 & 41.7 & 1.7 & 43.9 & 2.2 & 33.1 \\
\hline Carex spp. & GGL & $10 \mathrm{~m}^{2}$ & 33.3 & 30.0 & -3.3 & 50.0 & 20.0 & 46.1 & -3.9 & 32.2 & -13.9 & 31.9 \\
\hline Digitaria cognata & GGL & $10 \mathrm{~m}^{2}$ & 47.8 & 35.6 & -12.2 & 33.9 & -1.7 & 39.4 & 5.6 & 17.8 & -21.7 & 29.1 \\
\hline Buchloe dactyloides & WSG & $10 \mathrm{~m}^{2}$ & 38.9 & 27.8 & -11.1 & 42.8 & 15.0 & 35.0 & -7.8 & 20.0 & -15.0 & 27.4 \\
\hline Ruellia humilis & SF & $10 \mathrm{~m}^{2}$ & 33.3 & 34.4 & 1.1 & 26.7 & -7.8 & 34.4 & 7.8 & 21.7 & -12.8 & 25.1 \\
\hline Chamaesyce prostrata & A & $10 \mathrm{~m}^{2}$ & 37.8 & 33.3 & -4.4 & 16.7 & -16.7 & 37.2 & 20.6 & 17.2 & -20.0 & 23.7 \\
\hline Vernonia baldwinii & LF & $10 \mathrm{~m}^{2}$ & 31.1 & 40.6 & 9.4 & 10.0 & -30.6 & 35.0 & 25.0 & 18.9 & -16.1 & 22.6 \\
\hline Bouteloua gracilis & WSG & $10 \mathrm{~m}^{2}$ & 28.3 & 19.4 & -8.9 & 26.1 & 6.7 & 23.9 & -2.2 & 22.8 & -1.1 & 20.1 \\
\hline Dalea purpurea & LF & $10 \mathrm{~m}^{2}$ & 32.8 & 25.0 & -7.8 & 20.0 & -5.0 & 23.3 & 3.3 & 19.4 & -3.9 & 20.1 \\
\hline Salvia azurea & LF & $10 \mathrm{~m}^{2}$ & 13.9 & 27.8 & 13.9 & 25.6 & -2.2 & 31.1 & 5.6 & 19.4 & -11.7 & 19.6 \\
\hline Linum sulcatum & A & $10 \mathrm{~m}^{2}$ & 9.4 & 21.1 & 11.7 & 25.0 & 3.9 & 31.7 & 6.7 & 23.3 & -8.3 & 18.4 \\
\hline Aster oblongifolius & LF & $10 \mathrm{~m}^{2}$ & 18.9 & 18.9 & 0.0 & 17.2 & -1.7 & 20.0 & 2.8 & 24.4 & 4.4 & 16.6 \\
\hline Brickellia eupatorioides & LF & $10 \mathrm{~m}^{2}$ & 12.8 & 21.1 & 8.3 & 17.2 & -3.9 & 17.8 & 0.6 & 18.3 & 0.6 & 14.5 \\
\hline Artemisia Iuboviciana & SF & $10 \mathrm{~m}^{2}$ & 13.9 & 15.0 & 1.1 & 13.3 & -1.7 & 23.9 & 10.6 & 16.1 & -7.8 & 13.7 \\
\hline
\end{tabular}

${ }^{1} \mathrm{~A}$ indicates annual; GGL, grass and grass-like; LF, long-lived forb; SF, short-lived forb; WSG, warm-season grass.

pattern of species distribution, and observed that occupancy was positively correlated with abundance (measured as foliar cover). Collins and Glenn (1991) reported 17-20 core species (i.e., occupying greater than $90 \%$ of the samples) per year representing $7.3-12.2 \%$ of all species observed in the study. Both studies utilized $10-\mathrm{m}^{2}$ plots, and were conducted at the Konza Prairie Biological Station in the Flint Hills of northeastern Kansas.

In tallgrass prairies, annual spring burning promotes the dominance of warm-season grasses, and when coupled with grazing, produces a species-rich community dominated by

Table 3. Frequency estimates at the optimal frame size falling within an acceptable range of $15-55 \%$ for the 27 most abundant species at Tallgrass Prairie National Preserve.

\begin{tabular}{cccc}
\hline Year & $\begin{array}{c}\text { Observations within } \\
\text { desired range (\%) }\end{array}$ & $\begin{array}{c}\text { No. } \\
<15 \%\end{array}$ & $\begin{array}{c}\text { No. } \\
>55 \%\end{array}$ \\
\hline 2002 & $74.1 \%$ & 6 & 1 \\
2003 & $92.5 \%$ & 0 & 2 \\
2004 & $88.8 \%$ & 2 & 1 \\
2005 & $92.5 \%$ & 0 & 2 \\
2006 & $96.2 \%$ & 1 & 0 \\
\hline
\end{tabular}

grasses (Collins 1987; Collins and Steinauer 1998; Veen et al. 2008; Gibson 2009a; Spasojevic et al. 2010). Our sample design performed well by capturing the presence of 127 species and providing reliable estimates of abundance for common species. When ranked by optimized frequency in the order of increasing optimal plot size, the most abundant species of grasses are the same as the dominant species described for the Konza Prairie Biological Station (Table 2; Freeman 1998). Seven of the 10 most abundant species ranked by optimized frequency are also in the group of the 10 most abundant species when ranked by ocular estimates of foliar cover (James and DeBacker 2007).

The described process for determining optimized frequency and techniques for analyzing and reporting these data is applicable to any multiscale design, providing new tools for reporting useful information to land managers. These tools allow land managers to compare trends among species of interest in such a way that changes in frequency represent an equivalent, proportionate change in the species' abundance (e.g., Fig. 3). That is, those species with smaller optimal plot sizes are more abundant than those species with larger optimal plot sizes; however, comparable magnitudes of change from year to year for different species represent an equal proportion 


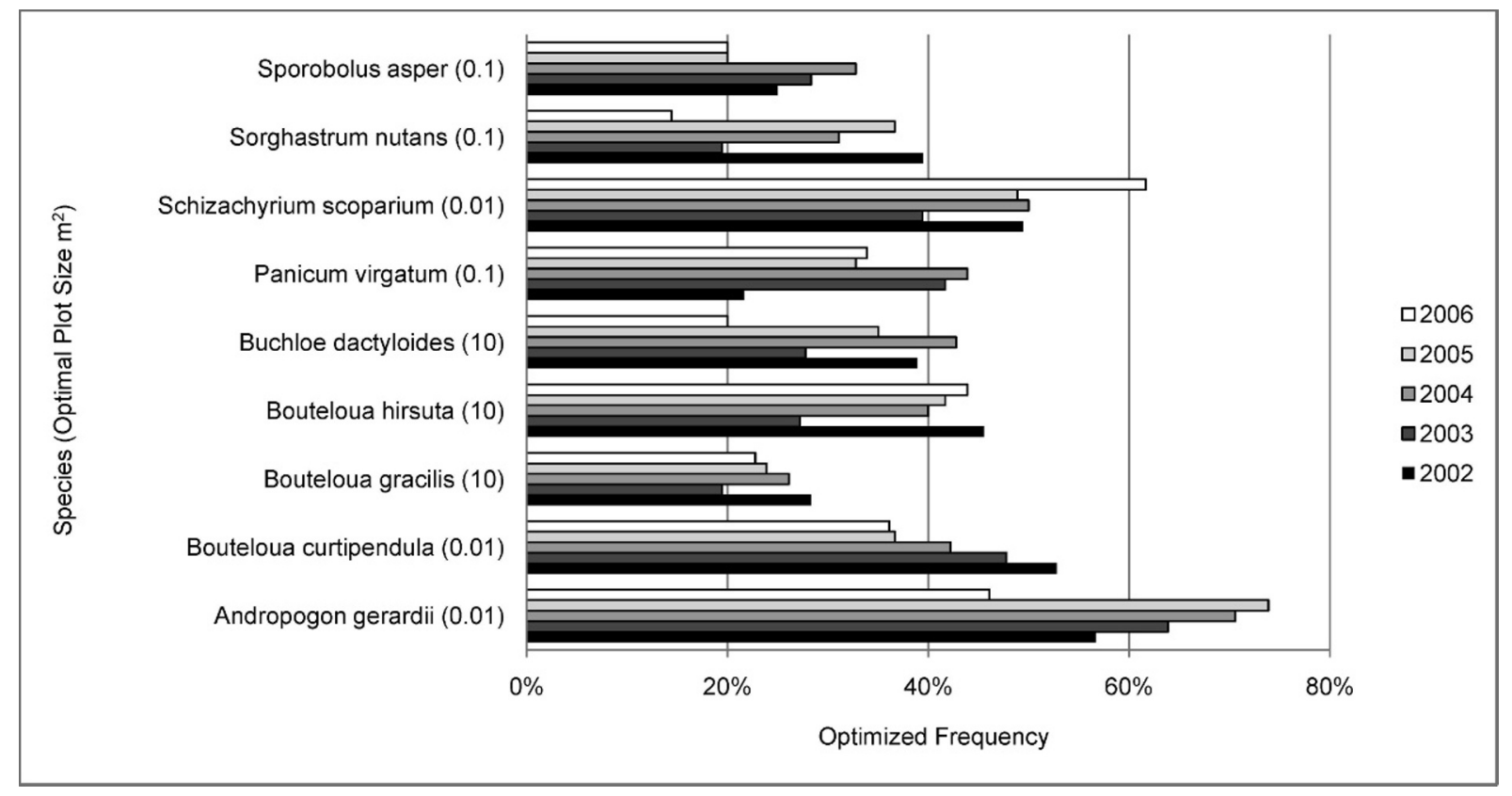

Figure 3. Optimized frequency and optimal plot size for nine warm-season grass species for 2002-2006. Changes in optimized frequency among species represent equivalent, proportionate changes in the species' abundance.

of each species' population (which would amount to more individuals of very abundant species).

Plotting the annual increases and decreases in optimized frequency over time (e.g., Fig. 4) provides a simple graphical tool for relaying the overall trajectory and amplitude of changes for the community. The amplitude and trajectory of changes in optimized frequency may be useful measures for monitoring ecosystem health. Trajectory indicates if, and to what extent, populations on average are increasing or decreasing from year to year. It should be noted that a trend toward increasing optimized frequency may not be desirable. For example, an increase in already abundant species may result in less interstitial space for satellite species. Amplitude indicates the magnitude of population size changes from year to year. No specific combination of trajectory (i.e., bigger populations vs. smaller populations) and amplitude (broader vs. narrower ranges) is arguably preferable. However, managers may be most interested in extreme values that may indicate strong directional changes in population size and/or a large magnitude of change from year to year, either of which may indicate a system in transition or going out of control and unable to recover.

In our study, amplitude and trajectory varied little over time. Between 2005 and 2006, the average change in optimized frequency was $-9.1 \%$, the only year with an overall declining trajectory. The declining trajectory between 2005 and 2006 was significantly different from the increasing trajectories observed between 2002 and 2003 (data not shown) and between 2004 and 2005. The amplitude of changes between 2005 and 2006 was $12.5 \%$, the largest observed, but not significantly different from other years.

With regard to the particular data presented in Figure 5, it is important to consider that year-to-year changes in optimized frequency for perennial species, particularly for long-lived perennial grasses, represent not only recruitment and mortality of entire individuals, but also increases and decreases in the number of shoots produced by persistent root systems. We cannot determine the relative contributions of these processes to the observed changes in frequency. However, it is likely that the observed changes for long-lived perennials represent mostly changes in shoot production (Briske and Derner 1998; Hartnett and Fay 1998; Gibson 2009b). This does not diminish the utility of these data for monitoring abundance, because trends in shoot production represent real trends in community structure, and a trend toward decreased shoot production will eventually be followed by a decrease in the abundance of individuals.

Optimal plot size depends on the underlying density and distribution of individuals in the population and may change over time, and from location to location. We define an acceptable range (i.e., $15-55 \%$ ) as the standard for determining if a new optimal plot size is required. If the plot size assigned to a species yields a frequency measure outside of the acceptable range, a new optimal plot size should be considered. Large fluctuations in abundance over time would require that different plot sizes be used in different years to yield an optimized frequency estimate within the acceptable range. In such a case, results may be reported simply as the number of species for which the optimal plot size increased, decreased, or remained the same.

The frequency of big bluestem (Andropogon gerardii) in the smallest plot exceeded the upper threshold in 4 of $5 \mathrm{yr}$, and thus a plot smaller than $0.01 \mathrm{~m}^{2}$ would be optimal for this species. Optimized frequency, however, may not be the best method for monitoring abundance when extremely small plots are required. A majority of the other measurements falling outside the acceptable range resulted from species with an average frequency near $15 \%$ in the largest frame size. From year to year, small changes in frequency caused these species to fluctuate above and below the $15 \%$ threshold. 

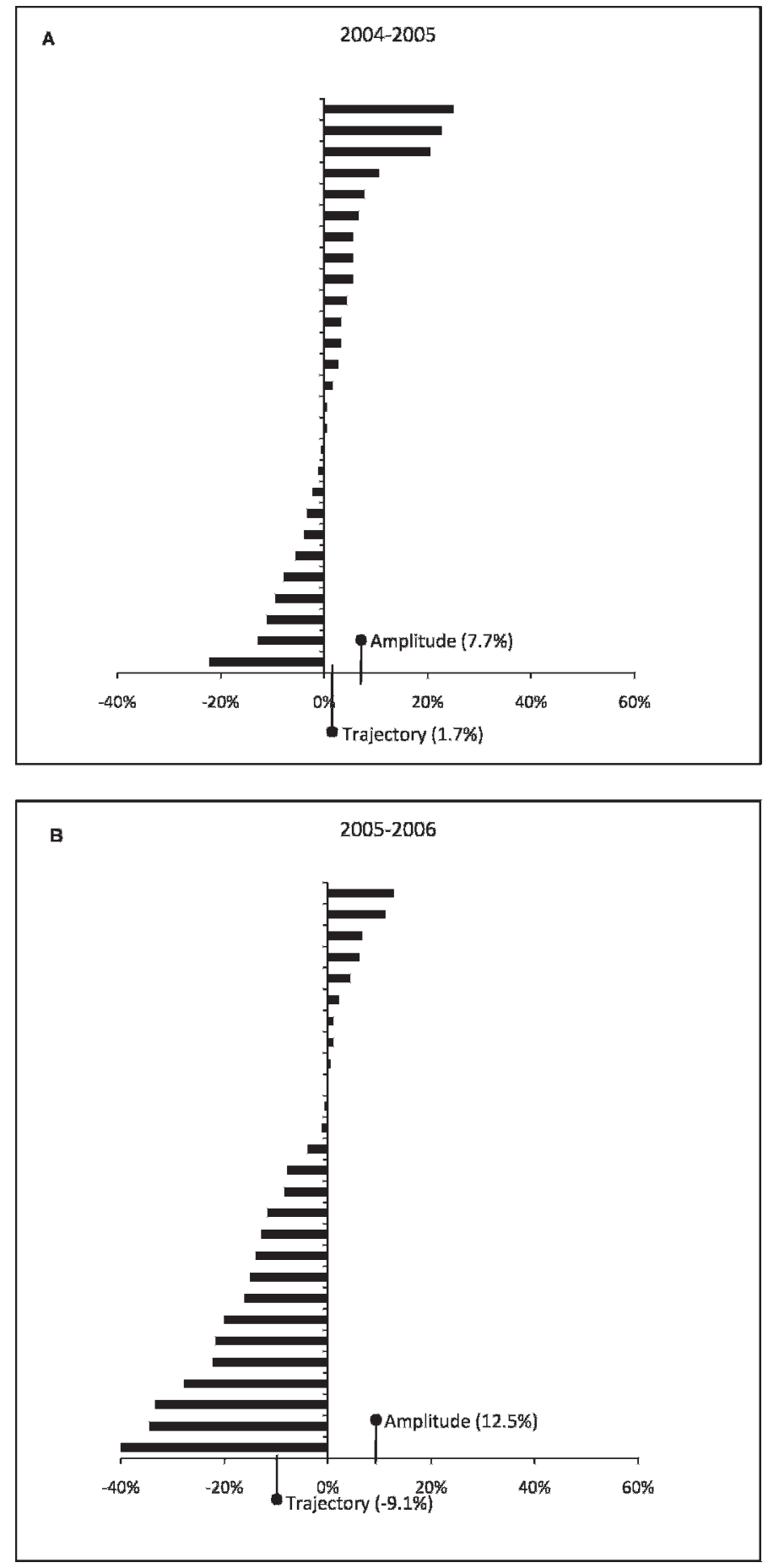

Figure 4. Distribution of interannual changes in optimized frequency for the 27 most abundant species at Tallgrass Prairie National Preserve: A, 2004 to 2005 and B, 2005 to 2006.

In our study, assigning species to an optimal plot size based on a 5 -yr average proved effective for obtaining comparable frequency measures from year to year. In other words, annual fluctuations in species' abundances were not great enough, for the most part, to produce frequency measures outside of an acceptable range. This permits the comparison of frequency measures from year to year from the same plot frame size (i.e., the optimal plot size for that particular species). The

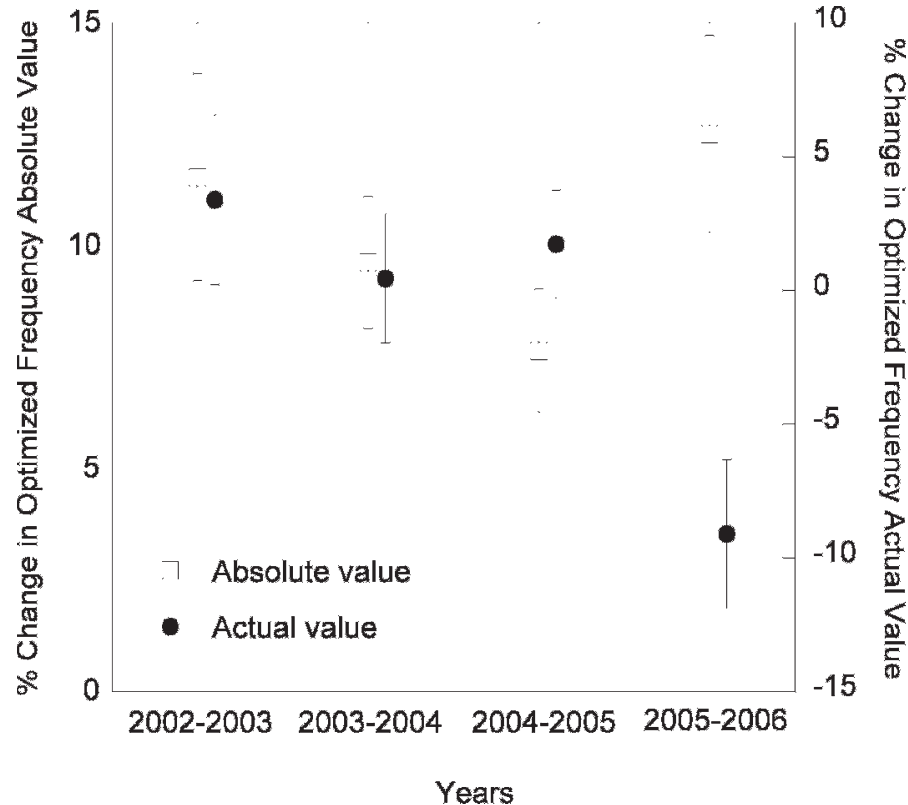

Figure 5. Yearly percentage of change in optimized frequency (mean \pm 1 SE) for the 27 most abundant species at Tallgrass Prairie National Preserve. Amplitude was calculated based on the absolute values of change for each species; trajectory was calculated based on the actual values.

consistency with which the optimal plot size delivers estimates in the acceptable range indicates overall stability.

\section{IMPLICATIONS}

Although multiscale monitoring designs are common (Peet et al. 1998; Stohlgren et al. 1998; James et al. 2009), there are few examples for reporting data from multiple spatial scales (Smith et al. 1987; Morrison et al. 1995; James and DeBacker 2007). Particularly scarce is guidance on aggregating information from multiple species collected at various spatial scales. We offer these techniques for aggregating information from multiple spatial scales to characterize the amplitude and trajectory of changes in species abundances as tools to help scientists convey the results of multiscale research projects to land managers.

\section{ACKNOWLEDGMENTS}

We thank Sherry Leis and Kevin James for their valuable comments on earlier drafts of this manuscript, and two anonymous reviewers.

\section{LITERATURE CITED}

Allen, L. J., L. H. Harbers, R. R. Schalles, C. E. Owensby, and E. F. Smith. 1976. Range burning and fertilizing related to nutritive value of bluestem grass. Journal of Range Management 29:306-308.

Anderson, K. L., E. F. Smith, And C. E. Owensby. 1970. Burning bluestem pasture. Journal of Range Management 23:81-92.

Anderson, R. C. 1990. The historic role of fire in the North American grassland. In: S. L. Collins and L. L. Wallace [EDS.]. Fire in North American tallgrass prairies. Norman, OK, USA: University of Oklahoma Press. p. 8-17.

Anderson, R. H., S. D. Fuhlendorf, and D. M. Engle. 2006. Soil nitrogen availability in tallgrass prairie under the fire-grazing interaction. Rangeland Ecology \& Management 59:625-631. 
Bartha, S., S. L. Collins, S. M. Glenn, and M. Kertesz. 1995. Fine-scale spatial organization of tallgrass prairie vegetation along topographic gradient. Folia Geobotanica \& Phytotaxonomica 30(2):169-184.

BragG, T. B. 1995. The physical environment of Great Plains grasslands. In: A. Joern and K. H. Keeler [EDS.]. The changing prairie. New York, NY, USA: Oxford University Press. p. 49-81.

Bragg, T. B., And L. C. Hulbert. 1976. Woody plant invasion of unburned Kansas bluestem prairie. Journal of Range Management 29:19-24.

Briske, D. D., and J. D. Derner. 1998. Clonal biology of ceaspitose grasses. In: C. P. Cheplick [ED.]. Population biology of grasses. Cambridge, United Kingdom: Cambridge University Press. p. 106-135.

Coluins, S. L. 1987. Interaction of disturbances in tallgrass prairie: a field experiment. Ecology 68:1243-1250.

Coluins, S. L. 1992. Fire frequency and community heterogeneity in tallgrass prairie vegetation. Ecology 73(6):2001-2006.

Colıins, S. L., AND D. J. GiBson. 1990. Effects of fire on community structure in tallgrass and mixed-grass prairie. In: S. L. Collins and L. L. Wallace [EDS.]. Fire in North American tallgrass prairies. Norman, OK, USA: University of Oklahoma Press. p. 81-98.

Collins, S. L., and S. M. Glenn. 1988. Disturbance and community structure in North America prairies. In: H. J. During, J. A. Werger, and J. H. Willems [EDs.]. Diversity and pattern in plant communities. The Hague, Netherlands: SPB Academic Publication. p. 131-143.

Collins, S. L., And S. M. GLenn. 1990. A hierarchical analysis of species' abundance patterns in grassland vegetation. American Naturalist 135(5):633-648.

Collins, S. L., AND S. M. GLenN. 1991. Importance of spatial and temporal dynamics in species regional abundance and distribution. Ecology 72:654-664.

Collins, S. L., and E. M. Steinauer. 1998. Disturbance, diversity and species interactions in tallgrass prairie. In: A. K. Knapp, J. M. Briggs, D. C. Hartnett, and S. L. Collins [EDS.]. Grassland dynamics: long-term ecological research in tallgrass prairie. New York, NY, USA: Oxford University Press. p. 140-156.

Freeman, C. C. 1998. The flora of Konza Prairie-a historical review and contemporary patterns. In: A. K. Knapp, J. M. Briggs, D. C. Hartnett, and S. L. Collins [EDS.]. Grassland dynamics: long-term ecological research in tallgrass prairie. New York, NY, USA: Oxford University Press. p. 69-80.

Funlendorf, S. D., AND D. M. Engle. 2001. Restoring heterogeneity on rangelands: ecosystem management based on evolutionary grazing patterns. BioScience $51: 625-632$.

Fuhlendorf, S. D., And D. M. Engle. 2004. Application of fire-grazing interaction to restore a shifting mosaic on tallgrass prairie. Journal of Applied Ecology 41:604-614.

Fuhlendorf, S. D., D. M. Engle, J. Kerby, and R. Hamilton. 2008. Pyric herbivory: rewilding landscapes through the recoupling of fire and grazing. Conservation Biology 23(3):588-598.

GiBson, D. J.. 2009a. Disturbance. In: D. J. GIBSon. 2009a. Grasses and grassland ecology. New York, NY, USA: Oxford University Press. p. 184-210.

GiBson, D. J.. 2009b. Population ecology. In: D. J. GiBson. 2009b. Grasses and grassland ecology. New York, NY, USA: Oxford University Press. p. 81-109.

Gibson, D. J., J. E. Ely, and S. L. Collins. 1999. The core-satellite species hypothesis provides a theoretical basis for Grime's classification of dominant, subordinate, and transient species. Journal of Ecology 87:1064-1067.

GotelLI, N. J., AND D. SimberLoff. 1987. The distribution and abundance of tallgrass prairie plants: a test of the core-satellite hypothesis. The American Naturalist 130(1):18-35.

GrIME, J. P. 1998. Benefits of plant diversity to ecosystems: immediate, filter and founder effects. Journal of Ecology 86(6):902-910.

Hanski, I. 1982. Dynamics of regional distribution: the core and satellite species hypothesis. Oikos 38:210-221.

Hartnett, D. C., and P. A. Fay. 1998. Plant populations: patterns and processes. In: A. K. Knapp, J. M. Briggs, D. C. Hartnett, and S. L. Collins [eds.]. Grassland dynamics: long-term ecological research in tallgrass prairie. New York, NY, USA: Oxford University Press. p. 81-100.

Heywood, J. S., And M. D. DeBacker. 2007. Optimal sampling designs for monitoring plant frequency. Rangeland Ecology \& Management 60(4):426-434.
HieBerT, R. D. [ed.]. 1998. Opportunities to enhance and maintain the tallgrass prairie ecosystem within the boundaries of Tallgrass Prairie National Preserve. Omaha, NE, USA: National Park Service, Midwest Region. 38 p.

James, K., AND M. DeBacker. 2007. Plant community monitoring trend report, Tallgrass Prairie National Preserve. Fort Collins, CO, USA: Department of Interior, National Park Service, Natural Resource Technical Report NPS/HTLN/ NRTR-2007/030. $44 \mathrm{p}$

James, K. M., M. D. DeBacker, G. A. Rowell, J. L. HaAck, and L. W. Morrison. 2009. Vegetation community monitoring protocol for the Heartland Inventory and Monitoring Network. Fort Collins, CO, USA: Department of Interior, National Park Service, Natural Resource Report NPS/HTLN/NRR—2009/141. 104 p.

Kansas Department of Agriculture. 2007. Bluestem pasture report. Available at: http://www.nass.usda.gov/Statistics_by_State/Kansas/Publications/Economics_ and_Misc/Bluestem/bluest07.pdf. Accessed 25 April 2007.

Knapp, A. K., J. M. Blair, J. M. Briggs, S. L. Collins, D. C. Hartnett, and L. C. Johnson. 1999. The keystone role of bison in North American tallgrass prairie. Bioscience 49:39-50.

Knapp, A. K., J. M. Briggs, D. C. Hartnett, and S. L. Coluins [eds.]. 1998. Grassland dynamics: long-term ecological research in tallgrass prairie. New York, NY, USA: Oxford University Press. 364 p.

Knapp, A. K., and T. R. SeAstedt. 1998. Introduction: grasslands, Konza Prairie, and long-term ecological research. In: A. K. Knapp, J. M. Briggs, D. C. Hartnett, and S. L. Collins [EDS.]. Grassland dynamics: long-term ecological research in tallgrass prairie. New York, NY, USA: Oxford University Press. p. 13-15.

Kutner, M. H., C. J. Nachtsheim, J. Neter, and W. LI. 2005. Applied linear statistical models. Boston, MA, USA: McGraw Hill Irwin. 1396 p.

Morrison, D. A., A. F. Lebrocoue, and P. J. Clarke. 1995. An assessment of some improved techniques for estimating the abundance (frequency) of sedentary organisms. Vegetation 120:131-145.

Norusis, M. J. 2008. SPSS 16.0 Statistical Procedures Companion. Upper Saddle River, NJ, USA: Prentice Hall. 630 p.

Peet, R. K., J. Wentworth, and P. White. 1998. A flexible multipurpose method for recording vegetation composition and structure. Castanea 63:262-274.

Rice, C. W., T. C. Todd, J. M. Blair, T. R. Seastedt, R. A. Ramundo, and G. W. T. Wilson. 1998. Belowground biology and processes. In: A. K. Knapp, J. M. Briggs, D. C. Hartnett, and S. L. Collins [EDS.]. Grassland dynamics: long-term ecological research in tallgrass prairie. New York, NY, USA: Oxford University Press. p. 244-264.

RobBins, M. B., and M. A. Ortega-Huerta. 2002. Major negative impacts of early intensive cattle stocking on tallgrass prairies: the case study of the greater prairie-chicken (Tympanuchus cupido). North American Birds 56:239-244.

Samson, F. B., and F. L. Knopf. 1994. Prairie conservation in North America. Bioscience 44:418-421.

Smith, M. D., and A. K. Knapp. 1999. Exotic plant species in C4-dominated grassland: invisibility, disturbance, and community structure. Oecologia 120:605-612.

Smith, M. D., And C. E. Owensby. 1978. Intensive-early stocking and season-long stocking of Kansas Flint Hills range. Journal of Range Management 31:14-17.

Smith, S. D., S. C. Bunting, and M. Hironaka. 1987. Evaluation of the improvement in sensitivity of nested frequency plots to vegetation change by summation. Great Basin Naturalist 47:299-307.

Spasojevic, M. J., R. J. Aicher, G. R. Koch, E. S. Marguardt, N. Mirotchnick, T. G. Troxler, and S. L. Collins. 2010. Fire and grazing in a mesic tallgrass prairie: impacts on plant species and functional traits. Journal of Ecology 91(6):1651-1659.

Stohlgren, T. J., K. A. Bull, and Y. OtsuKi. 1998. Comparison of rangeland vegetation sampling techniques in the central grasslands. Journal of Range Management 51(2):164-172.

Veen, G. F., J. M. BlaiR, M. D. Smith, and S. L. Collins. 2008. Influence of grazing and fire frequency on small-scale plant community structure and resource availability in native tallgrass prairie. Oikos 117:859-866.

Vinton, M. A., D. C. HaRtnett, E. J. Finck, and J. M. Briggs. 1993. Interactive effects of fire, bison (Bison bison) grazing and plant community composition in tallgrass prairie. American Midland Naturalist 129:10-18. 